DOI 10.18551/rjoas.2021-09.10

\title{
CONSTRAINTS IN DIGITAL TECHNOLOGY USAGE AND POSSIBLE SOLUTIONS: A CASE STUDY OF HORTICULTURAL FARMERS IN ACEH, INDONESIA
}

\author{
Kasimin Suyanti ${ }^{\star}$, Zakiah, Manyamsari Ira, Lecturers \\ Fuady Vaudhan, Postgraduate Student \\ Faculty of Agriculture, Syiah Kuala University, Banda Aceh, Aceh, Indonesia \\ Desparita Naya, Lecturer \\ Faculty of Agriculture, Almuslim University, Bireun, Aceh, Indonesia \\ *E-mail: suyantikasimin@unsyiah.ac.id
}

\begin{abstract}
The utilization of digital technology will improve horticultural agribusiness competitiveness. Digital technology makes it easy to make decisions and expands farmers' marketing network. The purpose of this research is to identify constraints towards digital technology utilization pertaining to horticultural farmers in the province of Aceh, and offer possible solutions. The study is exploratory and uses a qualitative descriptive analysis. The results show that farmers were not ready to use digital technology because of low education leading to inability to operate the technology, lack of funds, high variability of income due to very volatile selling price of horticultural products, and lack of facilities and infrastructure. To overcome these constraints it is necessary to provide socialization and training on digital technology adoption, working capital assistance, scholarships for farmers' families, and access to digital technology facilities and infrastructure at the local level. Strengthening the land tenure agrarian law and enactment of land conversion law would enable farmers to optimize their land utilization.
\end{abstract}

\section{KEY WORDS}

Horticulture, farmers, stakeholders, digital technology, access.

The use of digital technology in business will be able to increase the competitiveness of a company. The ease of access to digital technology makes it easy for people to eliminate obstacles in planning and will improve their future (Wilson et al., 2017). Company competitiveness can increase as this technology will enhance the company's accessibility to information. Generic technologies, such as mobile phones, facilitate access to input and output pricing information (Klerkx et al., 2019). Efficient agribusiness requires the support of various types of integrated digital technologies to access and implement them in their business (Ayre et al., 2019). Mastery of information will facilitate decision making and will increase production and marketing efficiency. Besides, the quality of design and innovation in digital technology can improve the convenience of service in inter-company cooperation (Foroudi et al., 2017).

The use of digital technology is essential because of the rapid change in technology systems, policies, socio-economic environment, literacy, and big data utilization. The use of big data in agribusiness would be able to lower operational costs (Hsieh et al., 2019). Digital technology can strengthen pathways to achieve business objectives through access to the internet enabling living interactions in the virtual environment (Huda, 2019). Difficulty in access to information will affect the quality of the company's services, such as service time to address damages and interference (Love \& Matthews, 2019).

All of these things would in turns affect the competitiveness of agribusiness including horticultural commodities. Demand for this commodity is very elastic, so its competitiveness is influenced by the price of substitute commodities (Sativa, 2017). The price of a horticultural commodity or product is strongly influenced by the quality, trends or preference, distribution time, and technology used in producing or handling it. Globalization and the change in food 
supply chains or networks have increased the chances of exports of horticultural products to developed countries (Barrett et al., 1999). The existence of digital technology will facilitate decision making and improve technology mastery, as well as the expansion of marketing network. Digital technology can ensure the sustainability of the business through a broader, more feasible, and easier-to-access business (Patrick \& Patrick, 2020).

The challenge in utilizing digital technology is the limitation of access to perpetrators, limited area access, high operational costs, lack of mastery over the management of digital technology, and lack of government support. The price for procurement and operation of digital technology becomes an obstacle in the utilization of digital technology (Kulkarni, 2018). Region spatial conditions influence accessibility to digital technology. Areas with high spatial heterogeneity require different infrastructures with more homogeneous spatial space (Tranos et al., 2013). For this, it is important to study the condition and access of horticultural farmers to the utilization of digital technology. The use of digital horticultural technology requires some readiness, that is the readiness of actors, land readiness, as well as innovation and technology readiness. The readiness of actors can be reflected in age, education level, level of literacy understanding and management of horticultural innovation and technology.

The purpose of this study is to assess the readiness of horticultural farmers and other stakeholders to use the digital technology. The study also attempts to compare the existing (real state) features of the farmers or farms with the characteristics that should exist (ideal state) in order to utilize the digital technology. Based on this comparison, constraints to digital technology utilization would be identified accordingly. By knowing the constraints, proper solutions for enhancing the farmers' readiness to digital technology utilization could be formulated appropriately. This is important for the farmers because digital systems can improve agricultural productivity through automation systems, interconnectedness, thorough monitoring, and problem-solving through model predictions (Fielke et al., 2019).

\section{METHODS OF RESEARCH}

This study is conducted using a survey in the production centers of major horticultural commodities, namely potatoes, chili pepper, and oranges, in the districts of Bener Meriah and of Central Aceh, both in Aceh--a well known Indonesia's province which was severely hit by the great tsunami in 2004. The survey, involving 30 horticultural farmers and 20 main stakeholders, was undertaken in June 2020. The main stakeholders consist of collector merchants, wholesalers, agricultural extension workers, heads of agriculture/horticultural departments, and community leaders. These samples were determined by using nonprobabilistic method, based on their availability during the time of survey. The data were collected using a prepared questionnaire.

The method of analysis is a descriptive qualitative approach. Data are processed and presented in form of tables. The analysis is then carried out as follows. Firstly, we measure the perpetrators' readiness through the characteristics of farming, land utilization, and technological characteristics of innovation in the development of horticultural agribusiness in Aceh. Secondly, comparison is made between the existing real condition and the ideal condition for utilizing the digital technology. Thirdly, identification of constraints in the utilization of digital technology. Fourthly, we provide troubleshooting recommendations based on feed backs obtained from the farmers and the stakeholders.

The ideal conditions for agriculture that are expected to enter the digital era according to Line Jobs in Warta Ekonomi (2019) are: the age of the actors is relatively young, the level of education of farmers is relatively high, the creation of innovation is relatively high, the increase in production is relatively high, marketing of products through online and computer use and relatively mandatory internet. Line Jobs in Warta Ekonomi (2019) also explains the importance of ideal agricultural land conditions for agriculture to enter the digital era, namely: the relatively low amount of idle land, low land rental prices, large land ownership, high farmer land ownership rates and land conversion rates are low. 


\section{RESULTS AND DISCUSSION}

Here we assess capacity of actors to utilize the digital technology based on the characteristics of horticultural farmers and of the main stakeholders. Table 1 shows that the horticultural farmers have an average age of approximately 40 years, with high school education level. To be more adaptive and highly competitive, the farmers are required to be younger and to be more familiar with the digital technology they should be college graduates. Obstacles in the development of Agribusiness are old-age farmers together with climate change and land area decline (Kaburuan et al., 2019).

Table 1 - Characteristics of the Sampled Horticultural Farmers in Aceh, 2020

\begin{tabular}{llllll}
\hline Characteristics & Chili Farmer & Potato farmer & CitrusFarmer & Horticultural farmer & Ideal Standard \\
\hline 1. Age (year) & 43.8 & 37.1 & 38.5 & 39.8 & $<40$ \\
2. Education (years) & 13.6 & 12.8 & 12.5 & 12.9 & $>16$ \\
3. Experience (years) & 18.8 & 14.3 & 3.5 & 12.2 & $>20$ \\
4. Land size (hectare, Ha): & & & & & $>3$ \\
• Own & 0.9 & 0.68 & 2.0 & 1.19 & $<0$ \\
$\quad$ Rent & 0.0 & 0.85 & 0.0 & 0.28 & $>1$ \\
5. Horticultural land $(\mathrm{Ha})$ & 0.3 & 1.0 & 0.3 & 0.23 & $<3,000,000$ \\
6. Rent of land (Rp/Ha) & $5,000,000$ & $4,000,000$ & $3,000,000$ & $4,000,000$ & 33.1 \\
7. Production (ton) & 1.5 & 20.0 & 4.5 & 26.0 & 17,3 \\
8. Productivity (ton/Ha) & 5.0 & 20.0 & 15.0 & 11.3 & \\
\hline
\end{tabular}

Note: * USD 1 approximately equals $R p$ 14,500.

The farmers have farming experience of around 12 years, but for the citrus farmers only 3.5 years. The area of owned land is around $1.2 \mathrm{Ha}$, but the one used for horticulture is only $0.23 \mathrm{Ha}$ (around $20 \%$ of the total), which is far below the ideal standard. Rent of the land is relatively high in the study areas, average of which is 4 million rupiahs per hectare annually. Where high land rent will increase production costs and lower competitiveness, low land utilization may lower operational efficiency. These lead to limits the use of quality inputs in the horticultural farms. As a result, productivity or yield is only 11.3 tons/Ha or only around 65.3 percent of the ideal level of 17.3 tons/Ha. Some research results demonstrate the role of digital technology in the process of production can increase the productivity, widen access to customers, and reduce operating costs (Khin \& Ho, 2019).

Low land productivity will generate low farming income as well. Low income will lower the ability of farmers to provide funds for farming operations and for purchasing supporting tools including digital technology. Combining several business units for collecting information needed by the businesses can lower operational costs and increase efficiency (Hsieh et al., 2019). Horticultural farmers requires the use of appropriate technology so as to be able to develop more competitively as digital farming (Rotz et al., 2019). But the horticultural farms face several constraints as mentioned above. The amount of digital technology utilization in modern agribusiness reaches only 5 percent, much lower than that in the new banking businesses which is 17 percent (Mathew Martin \& Rabindranath, 2017). The digital technology utilization in horticultural farms in Aceh is only 30 percent.

As in the case of the horticultural farmers, the capacity of main stakeholders of the horticultural farms to utilize the digital technology may also be categorized as relatively low. This is reflected from their average age of around 47 years, which is relatively old (Table 2). The level of education is also relatively low, only differ by around two years from the farmers. Moreover, the main stakeholders' land utilization for horticulture farms is only 56.5 percent, in other words the sleeping land is quite high (43.5 percent). Actually, almost 75 percent of the main stakeholders use smart phone, but their usage of the phone is only for basic communication purposes, far below the smart phone potential as a digital technology tool relevant for the horticultural businesses. The heavy work loads, as reflected by high numbers of target groups and target farmers they must serve, perhaps take up all their working time non-enabling them to make preparation and utilize of the digital technology.

The high degree of income obtained from outside horticultural/agribusiness, the people's perception that farming is of low social status, the fact that more younger people 
involved in urbanization process (Rye et al., 2018), together with the constraints mentioned above play an important role in limiting the implementation of digital technology in agribusiness.

Table 2 - Characteristics of Sampled Main Stakeholders of Horticultural Farms in Aceh, 2020

\begin{tabular}{|c|c|c|c|c|c|c|}
\hline Characteristics & $\begin{array}{l}\text { Collector } \\
\text { Merchants }\end{array}$ & $\begin{array}{l}\text { Whole- } \\
\text { salers }\end{array}$ & $\begin{array}{l}\text { Extension } \\
\text { Workers }\end{array}$ & $\begin{array}{l}\text { Community } \\
\text { Leaders }\end{array}$ & $\begin{array}{l}\text { Heads of Agri. } \\
\text { Depts. }\end{array}$ & Average \\
\hline Age (year) & 39.2 & 46.0 & 47.2 & 46.0 & 54.5 & 46.6 \\
\hline Education (years) & 12 & 14 & 16 & 12 & 20 & 14.8 \\
\hline $\begin{array}{l}\text { Average number of target } \\
\text { groups (units) }\end{array}$ & 10 & 17 & 45 & 11 & 1,595 & 336 \\
\hline $\begin{array}{l}\text { Number of target farmers } \\
\text { (persons) }\end{array}$ & 50 & 250 & 327 & 150 & 41,500 & 8,449 \\
\hline Building area $(\mathrm{Ha})$ & 97 & 327 & 366 & 70 & $223,267.5$ & $44,825.5$ \\
\hline $\begin{array}{l}\text { Land utilized for } \\
\text { horticulture/farm (\%) }\end{array}$ & 82.5 & 75 & 50 & 50 & 25 & 56.5 \\
\hline $\begin{array}{l}\text { Smart phone/Andr-oid } \\
\text { utilization (\%) }\end{array}$ & 70 & 75 & 58 & 90 & 75 & 74.6 \\
\hline
\end{tabular}

There are three characteristics that might affect utilization of digital technology, namely characteristics of perpetrators, property which is of land, and innovation. Under these three characteristics, real conditions in the sample areas are compared to the ideal conditions, in order to assess the farmers' possibility to adopt the digital technology. The results are as presented in Table 3.

Table 3 - Farmers, Property, and Innovation Characteristics under Real and The Ideal Conditions

\begin{tabular}{|c|c|c|c|}
\hline No & Characteristics & Real Conditions & Ideal Conditions \\
\hline \multirow[t]{8}{*}{1.} & Farmers & & \\
\hline & Age (years) & 46.6 & $<40$ \\
\hline & Education (years) & 14.8 & $>16$ \\
\hline & Innovation creation & Enough & Aggressive \\
\hline & Productivity (percentage) & 70.4 & $>90$ \\
\hline & Online marketing (percentage) & 5 & 100 \\
\hline & HP android utilization (percentage) & 30 & 100 \\
\hline & Internet utilization (percentage) & 30 & 100 \\
\hline \multirow[t]{6}{*}{2.} & Property/Land & & \\
\hline & a. $\quad$ Land utilization (percentage) & 74.5 & 100 \\
\hline & Land rental price (Rp/Ha/year) & $4,000,000$ & $<2,000,000$ \\
\hline & Land tenure (own) & 70 & 100 \\
\hline & Land tenure Status & 70 & 100 \\
\hline & e. Land conversion rate & High & Low \\
\hline \multirow[t]{5}{*}{3.} & Innovation & & \\
\hline & a. $\quad$ Type of technology & Traditional & Modern \\
\hline & Fund for innovations & Not available & Available \\
\hline & Understanding of technology & Insufficient & Sufficient \\
\hline & Absorbent power of technology & Low & Moderate to high \\
\hline
\end{tabular}

As seen from Table 3, there are considerable gaps between the real conditions and the ideal ones. The gaps would reduce the possibility of adopting the digital technology. Gaps in the characteristics of the perpetrators occur because the perpetrators have less working capital, insufficient understanding of the operation of digital technology, less operational funds, and obtained very volatile selling prices of their horticultural products.

The presence of digital infrastructure in a region will be able to increase the attractiveness of the area (Tranos et al., 2013). Increased attractiveness will be able to increase revenue and land utilization opportunities, as well as innovation. The condition of the perpetrator and the development of innovation have significant gaps.

Integrated system mechanization needs to be done to increase horticultural food security. For that, it is necessary public policy mediation centered on the interests of the horticultural market, farmer autonomy, and crop diversification (Valencia et al., 2019). Export opportunities in horticultural products increase the wages of workers from the industry, especially in households with the lowest income (Van den Broeck et al., 2017). The adoption of digital technology can improve production, value-added creation, and welfare for the 
community (Ebert \& Duarte, 2018). All these things lead to the orientation of utilization towards neglected digital technologies.

Problem-solving is based on the advice of the stakeholder in increasing the use of digital technology for the development of horticultural agribusiness in Aceh. To access and disseminate information in need of new technologies and gadgets such as smartphones, computers, driverless cars, and other smart devices (Nasiri et al., 2020).

Table 4 - Problem-solving for Agribusiness Actors in the Digital Age

\begin{tabular}{|c|c|}
\hline Causes of problems & Problem-solving \\
\hline Uninterested youth agribusiness & Socialization, coaching and market assurance \\
\hline Low availability of education funds & Educational Scholarship for farm families \\
\hline Lack of coaching, less creative and lack of community support & Socialization, coaching and innovation applications \\
\hline Innovations are less developed, rising global temperatures & Choosing the appropriate commodity for high temperature \\
\hline Shortage of facilities and coaching & Construction and provision of facilities \\
\hline Not familiar and feel unnecessarily & Dissemination and assistance of soft capital \\
\hline $\begin{array}{l}\text { Distance access constraints, provision of quota and } \\
\text { operational funds }\end{array}$ & Provision of facilities and operational cost assistance \\
\hline
\end{tabular}

Table 5 shows that to cope with the high age and the low level of education of the perpetrator, the effort to be done is to increase the motivation of younger generations through market assurance to horticultural products as well as providing scholarships for farmer families. The absence of computer use can be solved by using smartphones, i.e., handphone Android (Wijetunga, 2014). Smartphone components and facilities are part of the business idea, while infrastructure is a component of the support for components and facilities (Nambisan, 2016). The existence of digital technology has improved access and discussion between the workforce to more exciting job opportunities (Rye et al., 2018). Increased production through improved cultivation technology and processing technology as well as adaptation to climate change. Digital technology impacts social relations, knowledge transfer, e-learning, global nature Preservation (Arts et al., 2015). Increased use of social media through the provision of facilities and infrastructure, construction, and assistance in operational costs.

Land harvesting affects the ability of agribusiness practitioners to access digital technology. Difficulties in accessing and utilizing digital technology will change the provision of production facilities (Wong et al., 2018). The height of the sleeping land will reduce the competitiveness of horticultural farming in this digital era. The absence of infrastructure and transportation services in horticultural agribusiness is exacerbated by the weak availability of technological infrastructure (Velaga et al., 2012). The following Table 5 shows the constraints for optimizing land utilization along with solving the problem.

Table 5 - Causes and troubleshooting of land availability in the Digital age

\begin{tabular}{lll}
\hline Real conditions & Causes of problems & Problem-solving \\
\hline a. Low land utilization & Disadvantages of working capital & Working capital assistance through zakat utilization \\
b. High land rental rates & Low land tenure & Rental and land sharing pricing \\
c. Low land tenure & Low land tenure & Land division and construction \\
d. Non-owner land tenure Status & No land grants & Land tenure law for farmers \\
e. Land conversion rate & No land conversion control & Agricultural land conversion restrictions act \\
\hline
\end{tabular}

Table 5 shows that the land utilization is relatively low due to the shortage of working capital and high land rental price, for that is the need of working capital assistance, and setting the cost of land rent. The combined contribution of physical, digital, human resources, and social relations in the utilization of technology is the design of solutions that suit diverse local conditions (Warschauer \& Newhart, 2016). Low land tenure status and high land conversion to the non-farm also cause land utilization is mal. The great causes of land conversion are occupation growth, opti devolution system, commercialization of crops (Hakizimana et al., 2017). The solutions provided are the procurement of legislation on the granting of land for farmers and strengthening the implementation of non-agricultural land conversion laws. 
Table 6 - Causes and problem-solving innovations in the Digital Era of Access

\begin{tabular}{lll}
\hline Real conditions & Causes of problems & Troubleshooter \\
\hline a. Types of technology & Low social, economical access & Technological socialization and innovation \\
b. Fund for innovations & Low social, economical access & Funding assistance for innovations and new technologies \\
c. Understanding of technology & Low education levels & Enhancement of applicative Education \\
d. Mastery of technology & Low education levels & Enhancement of applicative Education \\
\hline
\end{tabular}

The adoption of technology is influenced by the ability to adapt to technology, the provision of operational funds, and environmental changes to digital technology (Yoon et al., 2020). Problem-solving can be done through technological socialization and innovation, funding assistance, and enhancement of applicative education to digital technology. The policy that the government can take to narrow the digital divide is research creativity, education, government initiatives, digital literacy, skill enhancement, and regional growth (Pick \& Azari, 2008). The help of facilities such as access and reduction of costs can be obtained from large companies that want to incubate business (Mack et al., 2016).

\section{CONCLUSION}

Cause of low readiness of actors is old age, funds are not available, mastery of low technology, and the selling price of volatile products. Innovation will evolve if supported by the government. Government support is the development of technological cultivation, processing and marketing, and adjustments to climate change. Horticultural farmers will increase the use of digital technology through socialization, training, working capital assistance, operational funds assistance, and scholarships for farmer children. The policies were improved infrastructure, strengthening of agrarian law, and enhancement of land conversion laws.

\section{ACKNOWLEDGMENTS}

The author uttered appreciation and gratitude for the Syiah Kuala University, Ministry of Education and Culture, which gave the opportunity and funds to do this research.

\section{REFERENCES}

1. Arts, K., van der Wal, R., \& Adams, W. M. (2015). Digital technology and the conservation of nature. Ambio, 44, 661-673. https://doi.org/10.1007/s13280-015-0705-1

2. Ayre, M., Mc Collum, V., Waters, W., Samson, P., Curro, A., Nettle, R., Paschen, J. A., King, B., \& Reichelt, N. (2019). Supporting and practicing digital innovation with advisers in smart farming. NJAS - Wageningen Journal of Life Sciences, 90-91(November 2018), 100302. https://doi.org/10.1016/j.njas.2019.05.001

3. Barrett, H. R., Ilbery, B. W., Browne, A. W., \& Binns, T. (1999). Globalization and the changing networks of food supply: The importation of fresh horticultural produce from Kenya into the UK. Transactions of the Institute of British Geographers, 24(2), 159-174. https://doi.org/10.1111/j.0020-2754.1999.00159.x

4. Cheeseman, N., Lynch, G., \& Willis, J. (2018). Digital dilemmas: the unintended consequences of election technology. Democratization, 25(8), 1397-1418. https://doi.org/10.1080/13510347.2018.1470165

5. Ebert, C., \& Duarte, C. H. C. (2018). Digital Transformation. IEEE Software, 35(4), 1621. https://doi.org/10.1109/MS.2018.2801537

6. Fielke, S. J., Garrard, R., Jakku, E., Fleming, A., Wiseman, L., \& Taylor, B. M. (2019). Conceptualizing the DAIS: Implications of the 'Digitalisation of Agricultural Innovation Systems' on technology and policy at multiple levels. NJAS - Wageningen Journal of Life Sciences, 90-91(April), 100296. https://doi.org/10.1016/j.njas.2019.04.002

7. Foroudi, P., Gupta, S., Nazarian, A., \& Duda, M. (2017). Digital technology and marketing management capability: achieving growth in SMEs. Qualitative Market Research, 20(2), 230-246. https://doi.org/10.1108/QMR-01-2017-0014 
8. Guinan, P. J., Parise, S., \& Langowitz, N. (2019). Creating an innovative digital project team: Levers to enable digital transformation. Business Horizons, 62(6), 717-727. https://doi.org/10.1016/j.bushor.2019.07.005

9. Hakizimana, C., Goldsmith, P., Nunow, A. A., Roba, A. W., \& Biashara, J. K. (2017). Land and agricultural commercialization in Meru County, Kenya: evidence from three models*. Journal of Peasant Studies, 44(3), 555-573. https://doi.org/10.1080/03066150.2016.1260555

10. Henriksson, M., Witzell, J., \& Isaksson, K. (2019). All Change or Business as Usual? The Discursive Framing of Digitalized Smart Accessibility in Sweden. Transportation Research Procedia, 41(2018), 625-636. https://doi.org/10.1016/j.trpro.2019.09.112

11. Hsieh, C. C., Liu, C. Y., Wu, P. Y., Jeng, A. P., Wang, R. G., \& Chou, C. C. (2019). Building information modeling services reuse for facility management for semiconductor fabrication plants. Automation in Construction, 102(December 2018), 270-287. https://doi.org/10.1016/j.autcon.2018.12.023

12. Huda, M. (2019). Empowering application strategy in technology adoption: Insights from professional and ethical engagement. Journal of Science and Technology Policy Management, 10(1), 172-192. https://doi.org/10.1108/JSTPM-09-2017-0044

13. Hynan, A., Murray, J., \& Goldbart, J. (2014). "Happy and excited": Perceptions of using digital technology and social media by young people who use augmentative and alternative communication. Child Language Teaching and Therapy, 30(2), 175-186. https://doi.org/10.1177/0265659013519258

14. Kaburuan, E. R., Jayadi, R., \& Harisno. (2019). Design of an loT-based monitoring system for intelligence indoor micro-climate horticulture farming in Indonesia. Procedia Computer Science, 157, 459-464. https://doi.org/10.1016/j.procs.2019.09.001

15. Khin, S., \& Ho, T. C. F. (2019). Digital technology, digital capability, and organizational performance: A mediating role of digital innovation. International Journal of Innovation Science, 11(2), 177-195. https://doi.org/10.1108/IJIS-08-2018-0083

16. Klerkx, L., Jakku, E., \& Labarthe, P. (2019). A review of social science on digital agriculture, smart farming, and agriculture 4.0: New contributions and a future research agenda. NJAS - Wageningen Journal of Life Sciences, 90-91(October), 100315. https://doi.org/10.1016/j.njas.2019.100315

17. Kulkarni, M. (2018). Digital accessibility: Challenges and opportunities. IIMB Management Review, 31(1), 91-98. https://doi.org/10.1016/j.iimb.2018.05.009

18. Love, P. E. D., \& Matthews, J. (2019). The 'how' of benefits management for digital technology: From engineering to asset management. Automation in Construction, 107(July). https://doi.org/10.1016/j.autcon.2019.102930

19. Mack, E. A., Marie-Pierre, L., \& Redican, K. (2016). Entrepreneurs' use of the internet and social media applications. Telecommunications Policy, 41(2), 120-139. https://doi.org/10.1016/j.telpol.2016.12.001

20. Mathew Martin, P. J., \& Rabindranath, M. (2017). Digital Inclusion for Access to Information: A Study on Banking and Financial Institutions in India. SAGE Open, 7(3), 18. https://doi.org/10.1177/2158244017720479

21. Nambisan, S. (2016). Digital Entrepreneurship: Toward a Digital Technology Perspective of Entrepreneurship. Entrepreneurship: Theory and Practice, 41(6), 1029-1055. https://doi.org/10.1111/etap.12254

22. Nasiri, M., Ukko, J., Saunila, M., \& Rantala, T. (2020). Managing the digital supply chain: The role of smart technologies. Technovation March 102121. https://doi.org/10.1016/j.technovation.2020.102121

23. Orben, A., \& Przybylski, A. K. (2019). The association between adolescent well-being and digital technology use. Nature Human Behaviour, 3(2), 173-182. https://doi.org/10.1038/s41562-018-0506-1

24. Patrick, G., \& Patrick, H. (2020). Digital sustainable entrepreneurship: A business model perspective on embedding digital technologies for social and environmental value $\begin{array}{llll}\text { creation. Journal of Cleaner } & \text { Production, }\end{array}$ https://doi.org/10.1016/j.jclepro.2020.122817 
25. Pick, J. B., \& Azari, R. (2008). Global Digital Divide: Influence of Socioeconomic, Governmental, and Accessibility Factors on Information Technology. Information Technology for Development, 15(1), 43-51. https://doi.org/10.1002/itdj

26. Rotz, S., Gravely, E., Mosby, I., Duncan, E., Finnis, E., Horgan, M., LeBlanc, J., Martin, R., Neufeld, H. T., Nixon, A., Pant, L., Shalla, V., \& Fraser, E. (2019). Automated pastures and the digital divide: How agricultural technologies are shaping labor and rural communities. Journal of Rural Studies, 68(June 2018), 112-122. https://doi.org/10.1016/j.jrurstud.2019.01.023

27. Rye, J. F., Slettebak, M. H., \& Bjørkhaug, H. (2018). From Family to Domestic and Global Labour? A Decade of Proletarisation of Labour in the Norwegian Horticulture Industry. European Countryside, 10(4), 528-542. https://doi.org/10.2478/euco-2018-0030

28. Tranos, E., Reggiani, A., \& Nijkamp, P. (2013). Accessibility of cities in the digital economy. Cities, 30(1), 59-67. https://doi.org/10.1016/j.cities.2012.03.001

29. Valencia, V., Wittman, H., \& Blesh, J. (2019). Structuring Markets for Resilient Farming Systems. Agronomy for Sustainable Development, 39(2). https://doi.org/10.1007/s13593019-0572-4

30. Van den Broeck, G., Swinnen, J., \& Maertens, M. (2017). Global value chains, largescale farming, and poverty: Long-term effects in Senegal. Food Policy, 66, 97-107. https://doi.org/10.1016/j.foodpol.2016.12.003

31. Velaga, N. R., Beecroft, M., Nelson, J. D., Corsar, D., \& Edwards, P. (2012). Transport poverty meets the digital divide: Accessibility and connectivity in rural communities. Journal of Transport Geography, 21, 102-112. https://doi.org/10.1016/j.jtrangeo.2011.12.005

32. Warschauer, M., \& Newhart, V. A. (2016). Broadening our concepts of universal access. Universal Access in the Information Society, 15(2), 183-188. https://doi.org/10.1007/s10209-015-0417-0

33. Wijetunga, D. (2014). The digital divide objectified in the design: Use of the mobile telephone by underprivileged youth in Sri Lanka. Journal of Computer-Mediated Communication, 19(3), 712-726. https://doi.org/10.1111/jcc4.12071

34. Wilson, A., Tewdwr-Jones, M., \& Comber, R. (2017). Urban planning, public participation, and digital technology: App development as a method of generating citizen involvement in local planning processes. Environment and Planning B: Urban Analytics and City Science, 46(2), 286-302. https://doi.org/10.1177/2399808317712515

35. Wong, J. K. W., Ge, J., \& He, S. X. (2018). Digitization in facilities management: A literature review and future research directions. Automation in Construction, 92(October 2017), 312-326. https://doi.org/10.1016/j.autcon.2018.04.006

36. Yoon, C., Lim, D., \& Park, C. (2020). Factors affecting adoption of smart farms: The case of Korea. Computers in Human Behavior, 108(May 2019), 106309. https://doi.org/10.1016/j.chb.2020.106309

37. Yu, T. K., Lin, M. L., \& Liao, Y. K. (2017). Understanding factors influencing information communication technology adoption behavior: The moderators of information literacy and digital skills. Computers in Human Behavior, 71, 196-208. https://doi.org/10.1016/j.chb.2017.02.005 